\title{
Pengaruh Frekuensi Penampungan terhadap Kualitas Spermatozoa Sapi Bali
}

\author{
Maria Oktoviana Seuk \\ ${ }^{a}$ Fakultas Pertanian, Universitas Timor, Kefamenanu, TTU - NTT, 85613, Indonesia, email.
}

\section{Article Info}

Article history:

Received 17 Januari 2017

Received in revised form 20 Agustus 2018

Accepted 2 September 2018

DOI:

https://doi.org/10.32938/ja.v3i4.540

Keywords:

Sapi Bali

Semen

Frekuensi Penampungan

\section{Abstrak}

Penelitian ini dilakukan di Laboratorium dan kandang sapi Fakultas Pertanian Universitas Timor, Kelurahan Sasi selama 5 bulan yaitu dari awal Juli sampai November 2016, dengan tujuan untuk mengetahui pengaruh frekuensi penampungan terhadap kualitas spermatozoa sap bali. Semen hasil penampungan selanjutnya langsung di bawah ke laboratorium untuk dilakukan pemeriksaan awal. Pemeriksaan semen segar dalam penelitian ini meliputi pemeriksaan secara makroskopis dan mikroskopis, selanjutnya diberi perlakuan dengan metode yang digunakan dalam penelitian ini adalah metode eksperimen yang terdiri dari 3 perlakuan dan 3 ulangan sehingga terdapat 9 unit satuan percobaan. Perlakuan yang diuji terdiri dari: $\mathrm{R} 1=1$ minggu 1 kali penampungan, $\mathrm{R} 2=1$ minggu 2 kali penampungan, dan $\mathrm{R} 3=1$ min ggu 3 kali penampungan. Hasil penelitian tersebut dianalisis menggunakan Rancangan Acak Lengkap (RAL) dan apabila terdapat perbedaan antara perlakuan, maka akan dilanjutkan dengan Uji Duncan. Analisis deskriptif digunakan untuk menghitung volume, bau, warna, dan konsistensi (kekentalan) semen. Disimpulkan bahwa frekuensi penampungan 1 minggu 1 kali penampungan dapat menghasilkan hasil yang lebih baik dibandingkan dengan frekuensi penampungan 1 minggu 2 kali penampungan dan 1 minggu 3 kali penampungan, dan pada $\mathrm{pH}$ semen, bau semen, warna semen, dan konsistensi (kekentalan ) semen menunjukkan hasil yang tidak berpengaruh nyata.

\section{Pendahuluan}

Sapi bali merupakan sapi asli Indonesia dengan ciri yang berbeda dari bangsa sapi lainnya. Sapi bali berukuran sedang, dadanya dalam, tidak berpunuk dan kaki-kakinya ramping, kulitnya berwarna merah bata, cermin hidung, kuku dan bulu ujung ekornya berwarna hitam. Kaki di bawah persendian karpal dan tarsal berwarna putih. Kulit berwarna putih juga ditemukan pada bagian pantatnya dan pada paha bagian dalam kulit berwarna putih tersebut berbentuk oval Pada punggungnya selalu ditemukan bulu hitam membentuk garis (garis belut) memanjang dari gumba hingga pangkal ekor (Guntoro, 2002).

Sapi bali jantan berwarna lebih gelap bila dibandingkan dengan sapi bal betina. Warna bulu sapi bali jantan biasanya berubah dari merah bata menjadi coklat tua atau hitam legam setelah sapi itu mencapai dewasa kelamin sejak umur 1,5 tahun dan menjadi hitam mulus pada umur 3 tahun. Warna hitam dapat berubah menjadi coklat tua atau merah bata apabila sapi itu dikebiri. Ukuran badan berukuran sedang dan bentuk badan memanjang. Kepala agak pendek dengan dahi datar. Badan padat dengan dada yang dalam, tidak berpunuk dan seolah tidak bergelambir, kakinya ramping, agak pendek menyerupai kaki kerbau.

Dalam rangka meningkatkan produktivitas sapi bali, pejantan memberikan sumbangan yang lebih berarti dibandingkan dengan betina. Kemampuan pejantan menyebarkan materi genetik jauh lebih besar jika dibandingkan dengan betina. Pejantan dengan kualitas yang unggul sebagai pemacek penting untuk diperhatikan dalam program perkawinan dimana peran pejantan berpengaruh besar terhadap keberhasilan kebuntingan. Salah satu kriteria yang harus dipenuhi dalam menentukan keunggulan ternak sapi yang akan digunakan sebagai pejantan adalah berdasarkan kualitas dan kuantitas spermatozoanya.

Spermatozoa dibentuk di dalam testis melalui proses yang disebut spermatogenesis, tetapi mengalami pematangan lebih lanjut di dalam epididimis dimana sperma disimpan sampai ejakulasi. Spermatogenesis dimulai pada waktu pubertas yaitu sewaktu hewan mencapai dewasa kelamin. Ejakulah normal semen sapi berwarna krem sampai putih, semen dengan konsentrasi yang rendah akan terlihat bening, tembus cahaya dan volume semen berkisar antara 6-8 ml (Toelihere, 1981; Garner \& Hafez, 2000). Kualitas semen sapi bali yang digunakan untuk inseminasi buatan harus memenuhi persyaratan seperti volume warna, $\mathrm{pH}$, konsistensi, motilitas, konsentrasi, dan morfologi. Faktor-faktor yan mempengaruhi kualitas semen diantaranya adalah umur, bangsa ternak, genetik, lingkungan, pakan dan jenis pengencer yang digunakan (Gordon, 2004).

\section{Metode}

Penelitian ini dilakukan di Laboratorium dan kandang sapi Fakultas Pertanian Universitas Timor, Kelurahan Sasi selama 5 bulan yaitu dari awal Juli sampai November 2016. Ternak yang digunakan dalam penelitian ini adalah 1 ekor sapi bali jantan dewasa yang berumur \pm 5 tahun dan 1 ekor betina sebagai pemancing. Beberapa peralatan dan bahan seperti kandang jepit, vagina buatan, mikroskop, pipet tetes, tabung penampung semen, kertas tissue, kertas lakmus, objek glass, cover glass, gelas beker dan erlenmeyer, termometer, kapas, aluminium foil, oven, handcounter, haemocytometer. Bahan yang digunakan dalam penelitian ini adalah alkohol, vaselin, larutan hayem, larutan eosin, air hangat, dan semen segar.

Metode yang digunakan dalam penelitian ini adalah metode eksperimen dengan menggunakan Rancangan Acak Lengkap (RAL) yang terdiri dari 3 perlakuan dan 3 ulangan yang terdiri dari: R1= penampungan 1 minggu 1 kali, R2= penampungan 1 minggu 2 kali, R3= penampungan 1 minggu 3 kali. Variabel yang diamati dalam penelitian ini adalah kualitas dan kuantitas sperma yang meliputi: volume, warna, bau, konsistensi atau kekentalan, $\mathrm{pH}$ (derajat keasaman), gerakan massa dan gerakan individu, konsentrasi spermatozoa, spermatozoa hidup dan mati, abnormalitas spermatozoa.

Data kemudian dianalisis secara deskriptif yaitu warna, bau, dan konsistensi, sedangkan derajat keasaman $(\mathrm{pH})$, konsentrasi sperma, gerakan massa dan gerakan individu, spermatozoa hidup dan mati, abnormalitas digunakan analisis sidik ragam (ANOVA) dan apabila terdapat perbedaan di antara perlakuan, dilakukan dengan uji jarak berganda Duncan (Steel \& Torrie, 1989).

\section{Hasil dan Pembahasan}

Berdasarkan hasil pemeriksaan semen secara mikroskopis dan makroskopis (Tabel 1.), volume semen dilihat melalui skala yang tertera pada dinding tabung penampung. Menurut Almquist (1956), kisaran normal volume semen sapi bali antara 4-8 ml, sedangkan bau semen dapat langsung dicium pada tabung penampung dengan cara melewatkan tabung penampung semen di bawah lubang hidung. Semen yang normal pada umumnya memiliki bau amis khas disertai dengan bau dari hewan itu sendiri.

$\underline{\text { Tabel 1. Evaluasi Semen Secara Makroskopis dan Mikroskopis }}$

\begin{tabular}{clc}
\hline No. & Uraian & Hasil \\
\hline 1. & Volume & $7 \mathrm{ml}$ \\
2. & Warna & Putih krem \\
3. & Bau & Khas semen sapi \\
4. & Konsistensi & Kental \\
5. & pH & 7 \\
6. & Gerakan massa & +++ \\
7. & Gerakan individu & $80 \%$ \\
8. & Konsentrasi sperma & juta sel sperma/ml \\
9. & Spermatozoa hidup dan mati & $71,5 \%$ \\
10. & Abnormalitas spermatozoa & $15,33 \%$ \\
\hline
\end{tabular}

Keterangan: +++ : Gerakan massa sangat baik (gelombang besar, tampak gelap tebal, aktif dan cepat berpindah) 1000 juta sel sperma/ml semen: konsentrasi dari sperma $80 \%$ : Gerakan individu sangat baik

Semen sapi normal umumnya berwarna susu atau krem keputihan dan keruh, semen yang baik derajat kekentalannya akan bergerak sangat lambat mengikuti kemiringan tabung penampung dimana hampir semua atau sedikit lebih kental dari susu. Warna semen bervariasi antara warna susu, putih, coklat, kuning, dan krem. Semen sapi dan memunyai volume rendah tetapi konsentrasi spermatozoa tinggi, sehingga memperlihatkan warna krem atau warna susu (Toelihere, 1981). Sedangkan keasaman atau pH semen dapat dilihat dengan cara celupkan kertas lakmus ke dalam semen yang sudah ditampung hingga menunjukkan angka keasaman.

Gerakan massa sperma dinilai berdasarkan kecenderungan sperma bergerak ke satu arah dan dilihat di bawah pembesaran mikroskop $10 \times 100$. Gerakan individu mencerminkan daya hidup spermatozoa dengan rata-rata yang berguna untuk menilai fertilitas pejantan sedangkan konsentrasi sperma merupakan jumlah sperma per ml semen dan dilihat di bawah pembesaran mikroskop $10 \times 40$. Konsentrasi semen yang lebih pekat pada umumnya mempunyai konsentrasi sperma yang lebih tinggi 1.000 juta sel atau lebih sel spermatozoa per ml semen (Toelihere, 1985).

Untuk menghitung volume semen dapat dilihat melalui skala yang tertera pada dinding tabung penampung, dan setiap kali ejakulasi Sapi Bali jantan pada umumnya menghasilkan $5 \mathrm{ml}$ sampai $8 \mathrm{ml}$. Dari Tabel. 2 dapat dilihat bahwa rataan volume semen yang diperoleh selama penelitian adalah memiliki rata-rata 4,6 ml. Menurut pendapat (Toelihere, 1993 dalam Susilawati, 2013) menyatakan bahwa volume semen sapi bervariasi antara 1.0 sampai $15.0 \mathrm{ml}$. Sedangkan menurut (Partodihardjo, 1982) volume semen per ejakulasi pada sapi rata-rata 4$5 \mathrm{ml}$.

Tabel 2. Pengaruh Perlakuan terhadap Volume Semen (ml)

\begin{tabular}{cccccc}
\hline \multirow{2}{*}{ Perlakuan } & \multicolumn{3}{c}{ Ulangan } & \multirow{2}{*}{ Jumlah } & \multirow{2}{*}{ Rata-rata } \\
\cline { 2 - 4 } & Minggu I & Minggu II & Minggu III & & \\
\hline R1 & 5 & 5 & 5 & 15 & 5,0 \\
R2 & 5 & 4 & 4 & 13 & 4,3 \\
R3 & 5 & 4 & 4 & 13 & 4,3 \\
\hline Total & & & & 41 & 4,6 \\
\hline
\end{tabular}


Tabel 3. Rata-Rata Standar Deviasi dan Koefisien Varian Warna Semen Sapi

\begin{tabular}{cccccc}
\hline No & Perlakuan & $(\mathrm{Xi})$ & $(\overline{)}$ & $(\mathrm{xi}-\overline{)}$ & $\left(\mathrm{xi}-\bar{J}^{2}\right.$ \\
\hline 1 & $\mathrm{R} 1.1$ & 4 & 4 & 0 & 0 \\
2 & $\mathrm{R} 2.1$ & 4 & 2 & 2 & 4 \\
3 & $\mathrm{R} 3.1$ & 4 & 1,3 & 2,7 & 7,29 \\
4 & $\mathrm{R} 1.2$ & 4 & 4 & 0 & 0 \\
5 & $\mathrm{R} 2.2$ & 4 & 2 & 2 & 4 \\
6 & $\mathrm{R} 3.2$ & 4 & 1,3 & 2,7 & 7,29 \\
7 & $\mathrm{R} 1.3$ & 4 & 4 & 0 & 0 \\
8 & $\mathrm{R} 2.3$ & 4 & 2 & 2 & 4 \\
9 & $\mathrm{R} 3.3$ & 4 & 1,3 & 2,7 & 7,29 \\
\hline Jumlah & & 21,9 & & 33,87 \\
\hline Rata-rata & & 2,43 & & 3,76 \\
\hline
\end{tabular}

Untuk mengetahui warna semen dapat diamati langsung melalui tabung penampung karena tabung penampung tersebut terbuat dari gelas plastik tembus pandang sehingga warna semen dapat dilihat langsung pada tabung penampung tersebut. Warna semen sapi normal pada umumnya berwarna putih krem. Warna semen yang didapatkan selama penelitian dari 6 kali penampungan dari seekor pejantan sapi bali adalah krem keputih-putihan, dan kemudian di analisis menggunakan Standar Deviasi (SD) menghasilkan rata-rata 0,19 dan Koefisien Variansi (KV) menghasilkan rata-rata $15,82 \%$. Menurut pendapat (Toelihere, 1985) bahwa semen sapi normal berwarna seperti susu atau krem keputih-putihan dan keruh. Derajat kekeruhannya tergantung pada konsentrasi sperma. Kebanyakan semen sapi jantan berwarna dengan variasi putih seperti susu sampai warna krem (Salisbury \& Van Demark, 1985). Semakin keruh warna semen biasanya jumlah sperma per ml semen itu semakin banyak (Partodihardjo, 1982).

Tabel 4. Rata-rata Standar Deviasi dan Koefisien Varian Bau Semen Sapi

\begin{tabular}{cccccc}
\hline No & Perlakuan & $(\mathrm{Xi})$ & $(\overline{)}$ & $(\mathrm{xi}-\overline{)}$ & $(\mathrm{xi}-)^{2}$ \\
\hline 1 & $\mathrm{R} 1.1$ & 2 & 2 & 0 & 0 \\
2 & $\mathrm{R} 1.2$ & 2 & 1 & 1 & 1 \\
3 & $\mathrm{R} 1.3$ & 2 & 0,67 & 1,33 & 1,76 \\
4 & $\mathrm{R} 2.1$ & 2 & 2 & 0 & 0 \\
5 & $\mathrm{R} 2.2$ & 2 & 1 & 1 & 1 \\
6 & $\mathrm{R} 2.3$ & 2 & 0,67 & 1,33 & 1,76 \\
7 & $\mathrm{R} 3.1$ & 2 & 2 & 0 & 0 \\
8 & $\mathrm{R} 3.2$ & 2 & 1 & 1 & 1 \\
9 & $\mathrm{R} 3.3$ & 2 & 0,67 & 1,33 & 1,76 \\
\hline Jumlah & & & 11,01 & & 13,81 \\
\hline Rata-rata & & & 1,22 & & 1,53 \\
\hline
\end{tabular}

Bau semen dapat langsung dicium pada tabung penampung dengan cara melewatkan tabung penampung semen di bawah lubang hidung, dan semen yang normal pada umumnya memiliki bau amis khas disertai dengan bau dari hewan itu sendiri. Bau semen yang diperoleh selama penelitian adalah normal, berbau amis khas, dan kemudian di analisis menggunakan Standar Deviasi (SD) menghasilkan rata-rata 0,19 dan Koefisien Varian (KV) menghasilkan rata-rata $15,82 \%$. Menurut pendapat Toelihere (1993) bahwa bau semen normal adalah berbau khas dari sapi itu sendiri dan bersifat merangsang.

Tabel 5. Rata-Rata Standar Deviasi dan Koefisien Varian Konsistensi (Kekentalan) Semen Sapi

\begin{tabular}{cccccc}
\hline No & Perlakuan & $(\mathrm{Xi})$ & $(\overline{)}$ & $\left(\mathrm{xi}^{-}\right)$ & $\left(\mathrm{xi}^{-}\right)^{2}$ \\
\hline 1 & $\mathrm{R} 1.1$ & 2 & 2 & 0 & 0 \\
2 & $\mathrm{R} 2.1$ & 2 & 1 & 1 & 1 \\
3 & $\mathrm{R} 3.1$ & 2 & 0,67 & 1,33 & 1,76 \\
4 & $\mathrm{R} 1.2$ & 2 & 2 & 0 & 0 \\
5 & $\mathrm{R} 2.2$ & 2 & 1 & 1 & 1 \\
6 & $\mathrm{R} 3.2$ & 2 & 0,67 & 1,33 & 1,76 \\
7 & $\mathrm{R} 1.3$ & 2 & 2 & 0 & 0 \\
8 & $\mathrm{R} 2.3$ & 2 & 1 & 1 & 1 \\
9 & $\mathrm{R} 3.3$ & 2 & 0,67 & 1,33 & 1,76 \\
\hline Jumlah & & & 11,01 & & 13,81 \\
\hline Rata-rata & & & 1,223 & & 1,534 \\
\hline
\end{tabular}

Konsistensi dari semen diperiksa dengan cara memiringkan tabung yang berisi sperma secara perlahan-lahan untuk mengetahui derajat kekentalannya. Semen yang baik derajat kekentalannya akan bergerak sangat lambat mengikuti kemiringan tabung penampung dimana hampir semua atau sedikit lebih kental dari susu. Konsistensi semen yang didapatkan dalam penelitian ini adalah kental, dan kemudian dianalisis menggunakan Standar Deviasi (SD) menghasilkan ratarata 0,19 dan Koefisien Varian (KV) menghasilkan rata-rata 15,82\%. Pada sapi, semen dengan konsistensi krem mempunyai konsentrasi 1000 juta sampai 2000 juta atau lebih sel per ml (Toelihere, 1993 dalam Susilawati, 2013). Semen yang baik derajat kekentalannya hampir sama atau sedikit lebih kental dari susu (Partodihardjo, 1987 dalam (Faqih, 2013). Menurut Salisbury dan Van Demark (1985) dalam (Afiati $d k k$.,2013) kekentalan dan sifat-sifat semen tergantung pada konsentrasi spermatozoa.

\subsection{Pengaruh Perlakuan terhadap Persentase Spermatozoa Hidup}

Dari Tabel 6. dapat dilihat bahwa penurunan persentase spermatozoa hidup semakin menurun seiring dengan frekuensi penampungan yang berturutturut yaitu 1 minggu 3 kali penampungan. Hasil analisis sidik ragam menunjukkan bahwa frekuensi penampungan dapat berpengaruh sangat nyata $(P<0,01)$ terhadap nilai persentase spermatozoa hidup. Hal ini disebabkan karena pada frekuensi penampungan yang berturut-turut dapat mengakibatkan sel spermatozoa berhenti bergerak karena tidak ada pasokan energi dari mitokondria, hal ini terjadi karena membran plasma tidak berfungsi dengan baik Menurut Palupi (2008), Membran plasma berfungsi untuk mengatur keluar masuknya zat-zat makanan.

Tabel 6. Rataan Persentase Spermatozoa Hidup (\%)

\begin{tabular}{|c|c|c|c|c|c|c|}
\hline \multirow{2}{*}{ Perlakuan } & \multicolumn{3}{|c|}{ Ulangan } & \multirow{2}{*}{ Jumlah } & \multirow{2}{*}{ Rataan } & \multirow{2}{*}{$\%$} \\
\hline & Minggu 1 & Minggu II & Minggu III & & & \\
\hline R1 & 181 & 173 & 189 & 543 & 181 & $90,5^{\mathrm{c}}$ \\
\hline R2 & 130 & 135 & 128 & 393 & 131 & $65,5^{\mathrm{b}}$ \\
\hline R3 & 121 & 112 & 118 & 351 & 117 & $58,5^{\mathrm{a}}$ \\
\hline Total & & & & 1287 & 429 & 71,5 \\
\hline
\end{tabular}

\subsection{Pengaruh Perlakuan terhadap pH Semen}

Rataan $\mathrm{pH}$ semen frekuensi penampungan menunjukkan bahwa perbedaan angka antara perlakuan R1 6,3 R2 6,3 dan R3 6. Hasil analisis sidik ragam menunjukkan bahwa perlakuan (R3) berbeda tidak nyata dengan perlakuan yang lain $(\mathrm{P}>0,05)$. Peningkatan $\mathrm{pH}$ semen yang diduga sperma menghasilkan asam laktat yang tinggi sehingga aktivitas sperma pada kondisi anaerob dimana sperma yang menghasilkan asam laktat semakin rendah nilai pHnya maka akan menyebabkan terjadi penurunan kualitas dari sperma tersebut (Soerensen, 1979).

Tabel 7. Rataan $\mathrm{pH}$ Spermatozoa

\begin{tabular}{cccccc}
\hline \multirow{2}{*}{ Perlakuan } & \multicolumn{3}{c}{ Ulangan } & \multirow{2}{*}{ Jumlah } & \multirow{2}{*}{ Rataan } \\
\cline { 2 - 4 } & Minggu 1 & Minggu II & Minggu III & & \\
\hline R1 & 7 & 6 & 6 & 19 & 6,3 \\
R2 & 7 & 6 & 6 & 19 & 6,3 \\
R3 & 6 & 6 & 6 & 18 & 6 \\
\hline Total & & & & 56 & 6,2 \\
\hline
\end{tabular}

\subsection{Pengaruh Perlakuan terhadap Konsentrasi Spermatozoa}

Tabel 8. menunjukkan bahwa semen yang ditampung pada waktu 1 minggu 1 kali tampung memiliki nilai konsentrasi yang lebih baik dibandingkan dengan nilai konsentrasi yang dihasilkan dari 2 kali tampung dalam seminggu dan 3 kali tampung dalam seminggu. Hasil analisis sidik ragam (ANOVA) menunjukkan bahwa frekuensi penampungan dapat berpengaruh sangat nyata $(\mathrm{p}<0,01)$ terhadap nilai konsentrasi spermatozoa. Hal ini disebabkan karena pada frekuensi penampungan yang berturut-turut dapat mengakibatkan penurunan terhadap nilai konsentrasi spermatozoa. Salisbury dan Van Demark (1985) dalam Butar (2009) menjelaskan bahwa konsentrasi spermatozoa yang berderajat tinggi biasanya berkisar dari $2000 \times 10^{6}$ sampai $2200 \times 10^{6}$ spermatozoa setiap mL. Hafez (2000) menjelaskan bahwa rendahnya konsentrasi pada semen sapi dapat dipengaruhi oleh beberapa faktor, di antaranya adalah kualitas pakan yang rendah.

Tabel 8. Rataan Konsentrasi Spermatozoa Sapi $\left(10^{6} \mathrm{sel} / \mathrm{ml}\right)$

\begin{tabular}{|c|c|c|c|c|c|}
\hline \multirow{2}{*}{ Perlakuan } & \multicolumn{3}{|c|}{ Ulangan } & \multirow[b]{2}{*}{ Jumlah } & \multirow[b]{2}{*}{ Rataan } \\
\hline & Minggu 1 & Minggu II & Minggu III & & \\
\hline R1 & 152 & 158 & 155 & 465 & 155 \\
\hline $\mathrm{R} 2$ & 108 & 101 & 115 & 324 & 108 \\
\hline R3 & 72 & 84 & 96 & 252 & 84 \\
\hline Total & & & & 1041 & 115,6 \\
\hline
\end{tabular}

\subsection{Pengaruh Perlakuan terhadap Abnormalitas Spermatozoa}

Abnormalitas bentuk sperma dalam satu contoh semen perlu diketahui karena tingkat abnormalitas tersebut akan berkaitan dengan kesuburan (fertilitas) dari pejantan yang ditampung semennya. Tingkat abnormalitas sperma dapat diketahui melalui preparat pewarnaan diferensial yang sudah diuraikan pada bagian persentase sperma hidup.

Hasil penelitian ini masih dalam batas normal abnormalitas spermatozoa untuk IB. Ini sesuai dengan yang dianjurkan Toelihere (1993) bahwa selama abnormalitas spermatozoa belum mencapai $20 \%$ dan tidak melebihinya maka spermatozoa masih dalam keadaan baik dan dapat dipakai untuk program IB. Menurut Hafez \& Hafez (2008) apabila jumlah spermatozoa abnormal sangat tinggi akan menurunkan tingkat fertilitas spermatozoa. Tabel 9. menunjukkan bahwa nilai rataan abnormalitas melebihi atas normal abnormalitas spermatozoa untuk IB, hal ini terjadi karena disebabkan oleh banyak faktor yaitu faktor suhu dan faktor lingkungan. Hal ini sesuai dengan pendapat Yudi $d k k$., (2010) menyatakan bahwa abnormalitas spermatozoa pada banyak kasus terjadi akibat gangguan termoregulasi dan hormonal di dalam testis yang disebabkan oleh lingkungan tidak cocok, lemak daerah inguinal dan skrotum, suhu lingkungan yang ekstrem, trauma dingin, peradangan skrotum dan testis, dermatitis, dan 
inguinalis. Faktor-faktor tersebut akan mempengaruhi hormon secara lokal atau sistemik, serta metabolisme spermatozoa sel sertoli.

Tabel 9. Rataan Abnormalitas Spermatozoa(\%)

\begin{tabular}{|c|c|c|c|c|c|c|}
\hline \multirow{2}{*}{ Perlakuan } & \multicolumn{3}{|c|}{ Ulangan } & \multirow{2}{*}{ Jumlah } & \multirow{2}{*}{ Rataan } & \multirow{2}{*}{$\%$} \\
\hline & Minggu 1 & Minggu II & Minggu III & & & \\
\hline R1 & 30 & 22 & 14 & 66 & 22 & 11 \\
\hline $\mathrm{R} 2$ & 28 & 26 & 24 & 78 & 26 & 13 \\
\hline R3 & 33 & 45 & 54 & 132 & 44 & 22 \\
\hline
\end{tabular}

\section{Simpulan}

Berdasarkan hasil penelitian disimpulkan bahwa dari ke sembilan variabel ini dapat dilihat bahwa pada frekuensi penampungan seminggu sekali memperoleh hasil yang lebih baik dibandingkan dengan frekuensi penampungan yang di lakukan seminggu 2 kali penampungan dan seminggu 3 kali penampungan.

\section{Pustaka}

Almquist, J. O \& E. B. Hale, 1956. An Approach to the Measurement of sexual Behavior and Semen Production in Dairy Bulls, III Internat. Congr. On. Anim.Repro.Cambridge.

Bernaseoni, G. 1995. Teknologi Kimia. Jakarta: PT Padya Pranita.

Djanuar. 1985. Fisiologi Reproduksi dan Inseminasi Buatan pada Sapi. Gajah Mada University Press. Yogyakarta.

Depkes RI. 2000. Pedoman Pelaksanaan pemantauan Garam Beryodium di Tingkat Masyarakat. Jakarta: Depkes RI.

Gomes, W.R. 1977. Artficial Insemination. Dalam H.H. Cole and P.T. Cupps ed. Reproduction in Animals. Academic Press, New York and London.

Hafez, E. S. E. 2000. Anatomy of Male Reproduction. Dalam E. S. E. Hafez (E.d)

Mumu, M. Ilyas. 2009. Viabilitas Semen Sapi Simmental yang Dibekukan Menggunakan Krioprotektan Gliserol. Makalah Ilmiah. Jurusan Peternakan Fakultas Pertanian Universitas Tadulako. Sulawesi Tengah.

Partodihardjo.1991. Ilmu Reproduksi Hewan. Jakarta: Produksi Mutiara.

Palupi, 2008. Garam. Beryodium, (Online), diakses tanggal 19 Mei 2011.

Pane. 1990. Membudidayakan Sapi Bali. Penerbit Kanisius. Yogyakarta.

Sudarmono,A.S. 2008. Sapi Potong. Penebar Swadaya. Depok. Jawa Barat.

Steel R. G. D., Torrie, J. H., 1995. Prinsip dan Prosedur Statistika: suatu pendekatan biometrik. Sumantri B. penterjemah. Jakarta: PT. Gramedia Pustaka Utama.

Solihati. 2008. Pengaruh Jenis Pengencer terhadap Motilitas dan Daya Tahan Hidup Spermatozoa Semen Cair Sapi Simmental. Makalah Ilmiah. Fakultas Peternakan Universitas Padjajaran, Bandung.

Sorensen, E.H. 1979. The Impact of Underwriting Method and Bidder Competition Upon Corporate Bond Interest Cost. The Journal of Finance, 34(4): 863-870.

Toelihere M.R. 1993. Inseminasi Buatan Pada Ternak. Angkasa Bandung.

Tomaszewska M, W, Sutama, I.K Gede Putu, I., dan Chaniago, T. D. 1991. Reproduksi Tingkah Laku dan Produksi Ternak di Indonesia. Jakarta: PT. Gramedia Pustaka Utama. 